\title{
Development of nitrogen-doped bamboo-like carbon nanotubes coated zeolite beads as "support on support" catalyst for the catalytic hydrogenation of olefins
}

\author{
László Vanyorek, et al. [full author details at the end of the article]
}

Received: 2 February 2019 / Accepted: 24 May 2019 / Published online: 29 May 2019

(c) The Author(s) 2019

\begin{abstract}
"Support on support" type catalysts were developed by applying catalytic chemical vapour deposition (CCVD). Nitrogen-doped bamboo-like carbon nanotubes (N-BCNT) were synthetized on the surface of zeolite beads by using four different metals ( $\mathrm{Ni}, \mathrm{Fe}, \mathrm{Co}$ and $\mathrm{V}$ ). Based on the thermogravimetric analysis (TGA), the Ni, $\mathrm{Co}$ and $\mathrm{Fe}$ were catalytically active for nanotube production on the zeolite surface. It was confirmed by SEM measurements, that the surface of the beads was extensively covered by N-BCNTs. Based on the TGA and SEM results, two SoS systems were selected for further catalysts development, which differed the most in their nanotube content (difference $11.63 \mathrm{wt} \%$ ) and surface coverage. These were two nickel containing samples with 6.72 and $18.35 \mathrm{wt} \% \mathrm{~N}-\mathrm{BCNT}$. Palladium nanoparticles were deposited $(1 \mathrm{wt} \%)$ on the surface of the N-BCNT/zeolite systems, and the final $\mathrm{Pd} /$ SoS catalysts were tested in hydrogenation of 1-butene. The conversion maximum $(\mathrm{X}=100 \%)$ was reached after $6 \mathrm{~min}$ in both cases independently of the nanotube content and coverage (WHSV: 5.49). To measure the lifetime of the selected catalysts, the WHSV was increased from 5.49 to 11 (by increasing the gas flow) and the systems were still active after $6 \mathrm{~h}$. Thus, the lifetime of the catalysts is longer than $6 \mathrm{~h}$. Furthermore, by increasing the gas flow (WHSV =11), higher conversion was achieved (98\%) with the sample which has a higher nanotube content Therefore, smaller carbon nanotube content is still as catalyst support. The final $\mathrm{Pd} / \mathrm{SoS}$ catalysts were active, easy to treat and removable from the reactors and could work with smaller carbon nanotube content as well. Thus, a more economical catalysts was developed, than a solely carbon nanotube-based counterparts which lack the zeolite core.
\end{abstract}

Keywords SoS catalyst $\cdot$ Palladium $\cdot$ Carbon nanotubes $\cdot$ Hydrogenation $\cdot$ Zeolite

Electronic supplementary material The online version of this article (https://doi.org/10.1007/s1114 4-019-01592-y) contains supplementary material, which is available to authorized users. 


\section{Introduction}

Different porous materials, such as zeolite, silica or activated carbon forms are regularly applied as catalyst supports in hydrogenation processes [1-4]. The mentioned support materials contain several micropores, thereby their surface areas are large. However, this feature, the presence of micropores in a catalytic system could limit the diffusion and, therefore, lower the reaction rates of the processes [5]. Furthermore, the catalytically active metal particles could be adsorbed in the micropores and thus, the accessible metal content of the catalyst could be decreased considerably. If other support materials such as carbon nanotubes (CNTs) are also included into the catalytic system besides the porous substrates (pellets, rings or beads), the above-mentioned problems can be reduced or avoided [6]. In this case, "support on support" (SoS) type catalysts are prepared which contain a "core" material (zeolite beads, pellets or others) support and carbon nanotubes as primary support for the catalytically active metal particles.

Carbon nanotubes are excellent catalyst supports, thanks to their extraordinary properties, such as high surface area, nanostructure, thermal stability, outstanding mechanical and electronic properties [7-9]. Carbon nanotube supported catalysts were successfully applied in hydro-desulfurization [10], hydro-formylation [11], Fischer-Tropsch synthesis [12], and oxidation [13]. The nanotubes were also effective support materials in hydrogenation reactions of various compounds including butene [14], ethyl-benzene [15], nitro-benzene [16], nitro-cyclohexane [17], and methyl-styrene [18]. The properties of CNTs can be further enhanced by incorporating nitrogen atoms into their structure which will led to the socalled nitrogen-doped bamboo-like carbon nanotubes (N-BCNTs). The structure of the N-BCNTs are altered compare to their nitrogen free counterparts. Further adsorption sites appear thanks to the incorporated nitrogen atoms, which will increase the potential interactions with the catalytically active metals and led to the formation of more effective heterogeneous catalysts [19-21]. However, N-BCNTs has high colloid stability in aqueous phase, because of the several dissociable functional groups in their structure and the graphene edges caused by the nitrogen atoms. Thus, the recovery of solely N-BCNT based catalysts is difficult [22]. But the problem can be handled by using additional support materials for the N-BCNTs in a "SoS" system, as it was mentioned above. To design an ideal catalytic system for hydrogenation, "SoS" catalysts were developed based on zeolite beads supported N-BCNTs which were decorated by catalytically active metal $(\mathrm{Pd})$. The activity of different $\mathrm{Pd} / \mathrm{SoS}$ were compared and the effect of the $\mathrm{N}-\mathrm{BCNT}$ content and coverage was studied. 


\section{Experimental}

\section{Materials and methods}

The nitrogen-doped bamboo-like carbon nanotubes were synthesized by employing the CCVD (Catalytic Chemical Vapour Deposition) process with n-butylamine (WVR) as carbon source. The catalysts were prepared by using one of the following metal salts, nickel(II) nitrate hexahydrate $\left(\mathrm{Ni}\left(\mathrm{NO}_{3}\right)_{2} \cdot 6 \mathrm{H}_{2} \mathrm{O}\right.$, Reanal), cobalt(II) nitrate hexahydrate $\left(\mathrm{Co}\left(\mathrm{NO}_{3}\right)_{2} \cdot 6 \mathrm{H}_{2} \mathrm{O}\right.$, Reanal), iron(III) nitrate nonahydrate $\left(\mathrm{Fe}\left(\mathrm{NO}_{3}\right)_{3} \cdot 9 \mathrm{H}_{2} \mathrm{O}\right.$, Reanal), or ammonium metavanadate $\left(\mathrm{NH}_{4} \mathrm{VO}_{3}\right.$, Reanal), in combination with Grace MS 5A zeolite beads (Roth) and Patosolv (mixture of aliphatic alcohols, WVR). The chemical composition of the applied zeolite is $\mathrm{Ca} /{ }_{\mathrm{n}} \mathrm{Na}_{12-2 \mathrm{n}}\left[\left(\mathrm{AlO}_{2}\right)_{12}\left(\mathrm{SiO}_{2}\right)_{12}\right] \cdot \mathrm{H}_{2} \mathrm{O}$. The pore size and the size of the beads are $\sim 5 \AA$ and $1.6-2.5 \mathrm{~mm}$, respectively. $\mathrm{Pd}\left(\mathrm{NO}_{3}\right)_{2} \cdot 2 \mathrm{H}_{2} \mathrm{O}$ (Reanal) was used to deposit the catalytically active $\mathrm{Pd}$ nanoparticles onto the surface of the N-BCNTs. 1-butene (purity: 99.5\%), hydrogen (purity: 99.999\%) and nitrogen (purity: 99.995\%) from Messer was applied to compare the activity of the catalysts in hydrogenation.

\section{Synthesis of the SoS catalysts}

The first step of the catalyst development was the impregnation of the zeolite beads with the transition metal salts. The zeolite beads were added to the aqueous solution of iron, cobalt, nickel and vanadium salts and the metal content was kept to $2 \mathrm{wt} \%$ in each case (Table 1). Thereafter the water was evaporated by using vacuum rotary evaporator. All samples were dried at $105^{\circ} \mathrm{C}$ overnight.

The impregnated zeolite beads were used as catalysts in the CCVD method to synthetize N-BCNTs. In each case, $2 \mathrm{~g}$ catalyst was placed in a quartz reactor and the synthesis were carried out for $30 \mathrm{~min}$. The carbon source was butylamine, which was added by a syringe pump $(6 \mathrm{ml} / \mathrm{h})$. Four different temperatures $(650,700,750$ and $800{ }^{\circ} \mathrm{C}$ ) were tested to select the optimal conditions. The efficacy of the procedures was compared based on the amount of the synthetized carbon nanotube.

In the final step of the catalyst development, palladium nanoparticles were deposited onto the surface of SoS beads. The N-BCNT coated zeolite $(1.2 \mathrm{~g})$ was impregnated by $1.5 \mathrm{ml} 2 \mathrm{wt} \%$ palladium solution $\left(1 \mathrm{~g} \mathrm{Pd}\left(\mathrm{NO}_{3}\right)_{2} \cdot 2 \mathrm{H}_{2} \mathrm{O}\right.$ in $50 \mathrm{ml}$ water $)$ which was added to $30 \mathrm{ml}$ distilled water. The water was evaporated and the $\mathrm{Pd}$

Table 1 Composition of the catalysts applied in the CCVD process to synthetize nitrogendoped bamboo-like carbon nanotubes (N-BCNTs)

\begin{tabular}{llll}
\hline Catalysts & Metal precursor & $\begin{array}{l}\text { Weight of the } \\
\text { precursor }(\mathrm{g})\end{array}$ & $\begin{array}{l}\text { Weight of } \\
\text { the zeolite } \\
(\mathrm{g})\end{array}$ \\
\hline $2 \% \mathrm{Fe} /$ zeolite & $\mathrm{Fe}\left(\mathrm{NO}_{3}\right)_{3} \times 9 \mathrm{H}_{2} \mathrm{O}$ & 2.89 & 19.60 \\
$2 \% \mathrm{Co} /$ zeolite & $\mathrm{Co}\left(\mathrm{NO}_{3}\right)_{2} \times 6 \mathrm{H}_{2} \mathrm{O}$ & 1.97 & 19.60 \\
$2 \% \mathrm{Ni} /$ zeolite & $\mathrm{Ni}_{\left(\mathrm{NO}_{3}\right)_{2} \times 6 \mathrm{H}_{2} \mathrm{O}}$ & 1.98 & 19.60 \\
$2 \% \mathrm{~V} /$ zeolite & $\mathrm{NH}_{4} \mathrm{VO}_{3}$ & 0.92 & 19.60 \\
\hline
\end{tabular}


impregnated SoS beads were dried at $120{ }^{\circ} \mathrm{C}$ overnight. The impregnated beads were heat-treated in nitrogen flow at $400{ }^{\circ} \mathrm{C}$ for $20 \mathrm{~min}$. Then, to form catalytically active $\mathrm{Pd}$ nanoparticles on the surface of the beads, the system was hydrogenated at $400{ }^{\circ} \mathrm{C}$ for $30 \mathrm{~min}$. The appearance of the palladium nanoparticles on the catalyst surface was confirmed by SEM-EDS measurements.

\section{Characterization techniques}

The presence and dispersity of N-BCNTs on the surface of the SoS samples were examined by Hitachi S4800 scanning electron microscopy (SEM). All SoS beads were glued onto the Carbon Tape surface. The N-BCNT content of the samples was measured by thermogravimetric analysis by using a Netzsh TG Tarsus instrument. The heat rate was $10{ }^{\circ} \mathrm{C} / \mathrm{min}$ and the measurements were carried out in oxidative atmosphere $\left(\mathrm{N}_{2} / \mathrm{O}_{2}\right.$ mixture, $14 \mathrm{ml} / \mathrm{min} / 6 \mathrm{ml} / \mathrm{min}$, respectively).

\section{Catalytic study of the SoS catalyst samples}

The catalytic activity of the samples was followed by a Bruker Vertex 70 Fourier transform infrared spectroscope, which was equipped with a gas cell. The atmospheric hydrogenation reactor system was connected to the gas cell in the infrared spectroscope (Fig. 1a-h). Nitrogen $(40 \mathrm{ml} / \mathrm{min})$, hydrogen $(40 \mathrm{ml} / \mathrm{min})$ and 1-butene (20 $\mathrm{ml} / \mathrm{min}$ ) was added to the system at atmospheric pressure. The hydrogen $/ 1$ butene molar ratio was $2: 1$. The temperature in the reactor was $50{ }^{\circ} \mathrm{C}$ and $0.5 \mathrm{~g} \mathrm{SoS}$ catalyst sample was used during all measurements. The weight hour space velocity (WHSV) was $5.49 \mathrm{~kg} 1$-butene $/ 1 \mathrm{~kg}$ catalyst/1 h.

The absorption band of the $\mathrm{C}=\mathrm{C}$ stretching vibration mode at $1646 \mathrm{~cm}^{-1}$ was used to follow the hydrogenation of 1-butene. The system was calibrated for five different 1-butene concentrations to ensure a properly linear quantitative response.

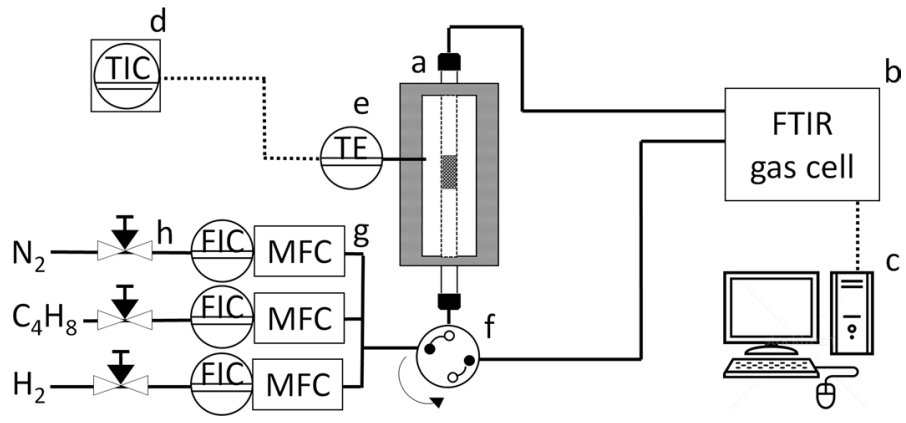

Fig. 1 Experimental setup to measure the catalytic activity of the developed "support on support" (SoS) catalysts in gas phase hydrogenation: a reactor with the catalyst in tube furnace, b, c FTIR instrument connected to a computer, d, e temperature indicator controller (TIC) with thermo element, f four-way valve for gas inlet into the reactor and the FTIR gas cell, $\mathbf{g}$ mass flow meter and controller, $\mathbf{h}$ valves for gases 
The efficacy of the catalytic hydrogenation was measure by the conversion (X\%) of 1-butene based on the following equation (Eq. 1):

$$
X \%=\frac{\text { consumed } n_{1-\text { butene }}}{\text { initial } n_{1-\text { butene }}} \times 100
$$

\section{Results and discussion}

\section{Characterization of the "Support on Support" beads}

The presence and dispersibility of nitrogen-doped carbon nanotubes on the surface of the zeolite was studied by SEM. The nanotubes can be clearly seen on the SEM pictures and their amount depend on the synthesis temperature and the metal used for impregnating the zeolite beads. The zeolite beads which were impregnated with cobalt, iron or nickel were effective in nanotube synthesis (SI, Fig. S1). Several carbon nanotubes can be located on the surface of these samples. However, the vanadium containing zeolite samples did not show catalytic activity and on the surface of these beads carbon nanotubes were not formed (SI, Fig. S1).

The SEM results were confirmed by thermogravimetric measurements. The $\mathrm{N}$-BCNT content of the samples prepared at different temperatures was defined by using the TG-DTG results (SI, Fig. S2). The carbon nanotube containing of the SoS catalysts can be seen in the Table 2 .

The inactivity of the vanadium containing samples during the CCVD procedure was striking. The nanotube content was less than $3.5 \mathrm{wt} \%$ at $750{ }^{\circ} \mathrm{C}$, and even less at other temperatures. On the surface of the iron containing zeolite beads $6.55 \mathrm{wt} \%$ N-BCNT was deposited at $750{ }^{\circ} \mathrm{C}$, which was the optimal condition as by decreasing or increasing the temperature the nanotube content was smaller. The nickel containing samples were quite effective and $18.35 \mathrm{wt} \%$ nanotubes formed at $650{ }^{\circ} \mathrm{C}$. The best sample in terms of nanotube formation was the one with $2 \mathrm{wt} \%$ cobalt at 650 and $700{ }^{\circ} \mathrm{C}$. In this case, $20 \mathrm{wt} \% \mathrm{~N}$-BCNT was deposited on the surface of the beads. Three significant steps can be seen on the TG curves. The mass loss from $\sim 350$ to $\sim 600{ }^{\circ} \mathrm{C}$ can be attributed to the ignition of carbon nanotubes. The initial temperature of the thermal oxidation of nanotubes in the case of each samples are different, owing to the different catalytic effect of the metals. Low ignition

Table 2 Carbon content of the zeolite beads

\begin{tabular}{llccr}
\hline CCVD Catalyst & \multicolumn{3}{l}{ Temperature } \\
\cline { 2 - 5 } & $650{ }^{\circ} \mathrm{C}$ & $700{ }^{\circ} \mathrm{C}$ & $750{ }^{\circ} \mathrm{C}$ & $800{ }^{\circ} \mathrm{C}$ \\
& \multicolumn{3}{l}{ Carbon content of the Zeolite-N-BCNT sup- } \\
& ports (wt $\%)$ & & \\
\hline $2 \%$ Fe/zeolite & 4.78 & 4.74 & 6.55 & 3.26 \\
$2 \%$ Co/zeolite & 20.04 & 20.23 & 17.9 & 10.80 \\
$2 \% \mathrm{Ni} /$ zeolite & 18.35 & 15.93 & 10.59 & 6.72 \\
$2 \% \mathrm{~V} /$ zeolite & 3.10 & 1.31 & 3.36 & 1.83 \\
\hline
\end{tabular}


temperature $\left(353{ }^{\circ} \mathrm{C}\right)$ was measured in the case of Co containing samples. The other two steps on the TG curves derives from the elimination of the adsorbed water and different organic compounds which formed during the decomposition of the carbon source of the nanotube synthesis (n-butylamine). Heat treatment was applied to remove these adsorbed components during the final $\mathrm{Pd} / \mathrm{SoS}$ catalyst preparation procedure.

Based on the SEM pictures and the TGA results, two Ni containing N-BCNT/ zeolite samples $\left(650\right.$ and $\left.800{ }^{\circ} \mathrm{C}\right)$ were chosen for further catalyst preparation. The nanotube content and coverage of the two samples varied the most (6.72 and 18.35 wt\%) within the prepared set of zeolite supported N-BCNTs. Thus, it can be tested whether more nanotube (a thick nanotube layer) is necessary or not to achieve high catalytic activity. Palladium nanoparticles were deposited onto the surface of the selected N-BCNT/zeolite beads, and the activity of the final Pd/SoS catalysts were tested using 1-butene hydrogenation as a test reaction.

\section{Characterization of the Pd/SoS catalysts}

The presence of palladium nanoparticles on the surface carbon nanotubes of the SoS catalysts was confirmed by SEM (Fig. 2a, b). The particle diameters were measured with the ImageJ program (Fig. 2c, d). The Pd particle size distribution on the surface of the two SoS catalysts is very similar. The mean particle diameter was $10.2 \mathrm{~nm}$ and $11.6 \mathrm{~nm}$, for the $6.72 \mathrm{wt} \%$ and for the $18.35 \mathrm{wt} \% \mathrm{~N}-\mathrm{BCNT}$ containing sample, respectively. $80 \%$ of the particles were between 4 and $14 \mathrm{~nm}$
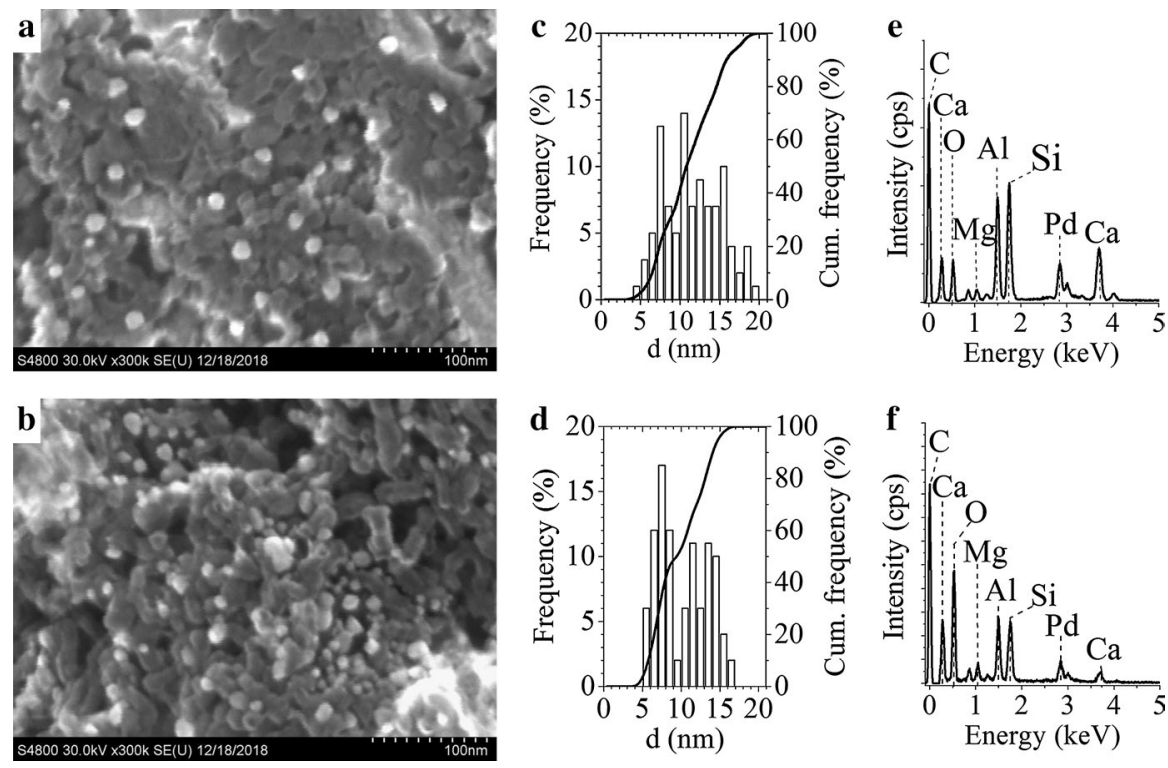

Fig. 2 SEM pictures with particle size distribution diagrams, and EDS spectrums of the palladium particle decorated $6.72 \mathrm{wt} \%(\mathbf{a}, \mathbf{c}, \mathbf{e})$ and $18.35 \mathrm{wt} \%(\mathbf{b}, \mathbf{d}, \mathbf{f}) \mathrm{N}-\mathrm{BCNT} / \mathrm{zeolite}$ SoS beads 
on the surface of the $6.72 \mathrm{wt} \%$ nanotube sample (Fig. 2c). In the case of the 18.35 wt $\%$ nanotube containing catalyst, most of the Pd particles $(80 \%)$ were between 6 and $13 \mathrm{~nm}$ (Fig. 2d). A small difference can be observed in the case of the maximum diameters as well (16 and $20 \mathrm{~nm}$ ), but apart from that, the Pd particles are not substantially different in the two catalysts. On the EDS spectrum several peaks can be identified, which can be attributed to Pd and other compounds of the zeolite beads (Fig. 2e, f).

\section{Catalytic tests of the $\mathrm{Pd} / \mathrm{SoS}$ catalysts}

Based on the catalytic tests, the butene conversion depends on the hydrogenation time (eq. 1). The conversion maximum $(X=100 \%)$ was reached after 6 min in both cases (Fig. 3a). The developed catalysts independently from their nanotube content were able to catalyse the hydrogenation process with maximum activity of 5.49 WHSV. The moles of hydrogenated butene per 1 mol palladium per min was calculated after 6 min hydrogenation. The amount of the hydrogenated 1-butene was $4.91 \mathrm{~mol}$ achieved by $1 \mathrm{~mol}$ palladium within $1 \mathrm{~min}$ in case of the $6.72 \mathrm{wt} \% \mathrm{~N}-\mathrm{BCNT}$ containing catalyst. By using the $18.35 \mathrm{wt} \%$ nanotube containing sample, the 1-butene consumption was somewhat lower $4.33 \mathrm{~mol}$.

To measure the lifetime of the selected catalysts, the WHSV was increased up to 11 (by increasing the gas flow) and the systems were still active after $6 \mathrm{~h}$. Thus, the lifetime of the catalysts is longer than $6 \mathrm{~h}$. Furthermore, by increasing the gas flow (WHSV =11), higher conversion was achieved (98\%) with the sample which has a higher nanotube content (Fig. 3b).
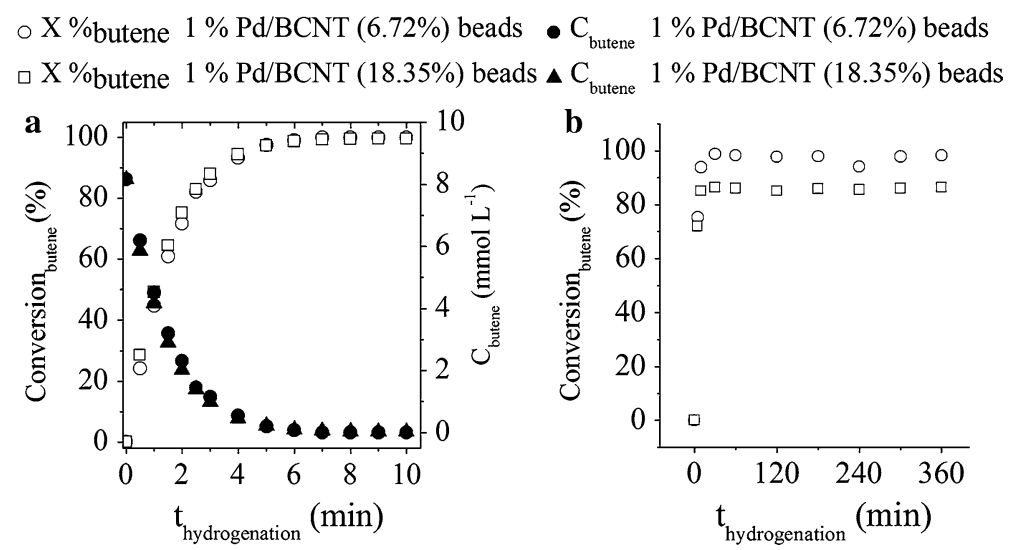

Fig. 3 The 1-butene conversion and change of concentration versus time of hydrogenation (a) and life time tests (b) in case of the developed SoS catalysts. N-BCNT content of the catalysts were $6.72 \mathrm{wt} \%$ and $18.35 \mathrm{wt} \%$ 


\section{Conclusion}

Palladium containing "support on support" type catalysts were developed for catalytic hydrogenation processes. The primer catalyst supports were the N-doped bamboo-like carbon nanotubes (N-BCNTs) which were deposited on the surface of zeolite beads used as the "core" of the system. The zeolite beads were impregnated with four different metals ( $\mathrm{Co}, \mathrm{Fe}, \mathrm{Ni}$ and $\mathrm{V}$ ) which were used as catalysts to deposit N-BCNTs onto the surface of the beads by using the CCVD method at different temperatures. The N-BCNT content of the system was measured by TGA and studied by SEM. Based on the TGA results, two Ni containing N-BCNT/zeolite samples $\left(650\right.$ and $800{ }^{\circ} \mathrm{C}$ ) were chosen for further catalyst preparation. The nanotube content and coverage of the two samples varied the most (6.72 and $18.35 \mathrm{wt} \%$ ) within the prepared set of zeolite supported N-BCNTs. On the surface of these samples, palladium nanoparticles were deposited (1 wt $\%$ ), and the final $\mathrm{Pd} / \mathrm{SoS}$ catalysts were tested in hydrogenation of 1-butene. The conversion maximum $(X=100 \%)$ was reached after 6 min hydrogenation in both cases. Catalytic activities of the two samples were compared based on following values: $4.91 \mathrm{~mol} 1$-butene was hydrogenated on $1 \mathrm{~mol} \mathrm{Pd}$ per $1 \mathrm{~min}$ in case of the $6.72 \mathrm{wt} \% \mathrm{~N}-\mathrm{BCNT}$ contained catalyst. By using of the $18.35 \mathrm{wt} \%$ nanotube contained sample was reached $4.33 \mathrm{~mol} 1$-butene consumption per $1 \mathrm{~mol} \mathrm{Pd}$ per min, by applying of 5.49 WHSV.

The lifetime of the catalysts was measured and it was found to be longer than $6 \mathrm{~h}$. During the lifetime tests the WHSV was increased from 5.49 to 11 (increased gas feed), and it led to different 1-butene conversions in case of the two catalysts. Higher 1-butene feed resulted different activity in case of both catalysts, despite the same Pd content and particle size. This can be associated with the different N-BCNT content of the catalysts and it shows that higher carbon nanotube content increased the catalytic activity of the samples (from 86 to $98 \%$ ). The final $\mathrm{Pd} / \mathrm{SoS}$ catalysts are active, easy to treat and removable from the reactors and could work with smaller carbon nanotube content as well. Therefore, these catalysts are more economical, than their solely carbon nanotube-based counterparts which lack the zeolite core.

Acknowledgements Open access funding provided by University of Miskolc (ME). This research was supported by the European Union and the Hungarian State, co-financed by the European Regional Development Fund in the framework of the GINOP-2.3.4-15-2016-00004 project, aimed to promote the cooperation between the higher education and the industry. Further support was provided within the framework of the EFOP-3.6.1-16-2016-00011 "Younger and Renewing University - Innovative Knowledge City - institutional development of the University of Miskolc aiming at intelligent specialisation" project which is implemented within the Széchenyi 2020 program and funded by the European Union, cofinanced by the European Social Fund.

\section{Compliance with ethical standards}

Conflict of interest On behalf of all authors, the corresponding author states that there is no conflict of interest.

Open Access This article is distributed under the terms of the Creative Commons Attribution 4.0 International License (http://creativecommons.org/licenses/by/4.0/), which permits unrestricted use, distribution, and reproduction in any medium, provided you give appropriate credit to the original author(s) and the source, provide a link to the Creative Commons license, and indicate if changes were made. 


\section{References}

1. Teh LP, Triwahyono S, Jalil AA, Mamat CR, Sidik SM, Fatah NAA, Mukti RR, Shishido T (2015) Nickel-promoted mesoporous ZSM5 for carbon monoxide methanation. RSC Adv 79:64651-64660

2. Yung MM, Starace AK, Mukarakate C, Crow AM, Leshnov MA, Magrini KA (2016) Biomass catalytic pyrolysis on Ni/ZSM-5: effects of nickel pre-treatment and loading. Energy Fuel 30:5259-5268

3. Pudukudy M, Yaakob Z, Akmal ZS (2015) Direct decomposition of methane over Pd promoted Ni/ SBA-15 catalysts. Appl Surf Sci 353:127-136

4. Muradov N, Smith F, T-Raissi A (2005) Catalytic activity of carbons for methane decomposition reaction. Catal Today 102-103:225-233

5. Mahata N, Soares OSGP, Rodríguez-Ramos I, Pereira MFR, Órfão JJM, Figueiredo JL (2013) Promotional effect of $\mathrm{Cu}$ on the structure and chloronitrobenzene hydrogenation performance of carbon nanotube and activated carbon supported Pt catalysts. Appl Catal B 464-465:28-34

6. Vanyorek L, Bánhidi O, Muránszky G, Sikora E, Prekob Á, Viskolcz B (2018) Chlorate elimination by catalytically hydrogenation, catalyst development and characterization. Catal 125:583-593

7. Collins PG, Arnold MS, Avouris P (2001) Engineering carbon nanotubes and nanotube circuits using electrical breakdown. Science 292:706-709

8. Yakabson BI, Smalley RE (1997) Fullerene Nanotubes: $\mathrm{C}_{1,000,000}$ and beyond. Am Sci 85:324-337

9. Rouff RS, Lorents DC (1995) Mechanical and thermal properties of carbon nanotubes. Carbon 33:925-930

10. Yu Z, Fareid LE, Moljord K, Blekkan EA, Walmsley JC, Chen D (2008) Hydrodesulfurization of thiophene on carbon nanofiber supported Co/Ni/Mo catalysts. Appl Catal B 84:482-489

11. Zhang Y, Zhang HB, Lin GD, Chen P, Yuan YZ, Tsai KR (1999) Preparation, characterization and catalytic hydroformylation properties of carbon nanotubes-supported Rh-phosphine catalyst. Appl Catal A 187:213

12. Bahome MC, Jewell LL, Hildebrandt D, Glasser D, Coville NJ (2005) Fischer-Tropsch synthesis over iron catalysts supported on carbon nanotubes. Appl Catal A 287:60-67

13. Ovejero G, Sotelo JL, Rodriguez A, Diaz C, Sanz R, Garcia J (2007) Platinum catalyst on multiwalled carbon nanotubes for the catalytic wet air oxidation of phenol. Ind Eng Chem Res 46:6449

14. Vanyorek L, Kristály F, Mihalkó A, Bánhidi O, Kónya Z, Kukovecz Á, Lakatos J (2015) Synthesis and 1-butene hydrogenation activity of platinum decorated bamboo-shaped multiwall carbon nanotubes. Reac Kinet Mech Cat 116:371-383

15. Chambers A, Nemes T, Rodriguez NM, Baker RTK (1998) J Phys Chem B 102:2251

16. Prekob Á, Muránszky G, Hutkai ZSG, Pekker P, Kristály F, Viskolcz B, Vanyorek L (2018) Hydrogenation of nitrobenzene over a composite catalyst based on zeolite supported N-doped carbon nanotubes decorated with palladium. Reac Kinet Mech Cat 125:583

17. Serp P, Corrias M, Kalck P (2003) Carbon nanotubes and nanofibers in catalysis. Appl Catal A 253:337-358

18. Pham-Huu C, Kelle N, Ehre G, Charbonniere LJ, Ziessel R, Ledoux MJ (2001) Carbon nanofiber supported palladium catalyst for liquid-phase reactions: an active and selective catalyst for hydrogenation of cinnamaldehyde into hydrocinnamaldehyde. J Mol Catal A 170:155

19. Ibrahim EMM, Khavrus VO, Leonhardt A, Hampel S, Oswald S, Rümmeli MH, Büchner B (2010) Synthesis, characterization, and electrical properties of nitrogendoped single-walled carbon nanotubes with different nitrogen content. Diamond Relat Mater 19:1199-1206

20. Li YH, Hung TH, Chen YH (2009) A first-principles study of nitrogen- and boron-assisted platinum adsorption on carbon nanotubes. Carbon 47:850-855

21. Ayala P, Arenal R, Rümmeli M, Rubio A, Pichler T (2010) The doping of carbon nanotubes with nitrogen and their potential applications. Carbon 48:575-586

22. Vanyorek L, Sikora E, Kiss A, Sike Á, Hutkai ZSG, Pekker P, Viskolcz B, Fiser B (2018) Nitrogendoped bamboo-shaped carbon nanotube supported catalysts for heterogeneous hydrogenation-the effect of surface polarity. Reac Kinet Mech Cat 125:37-46

Publisher's Note Springer Nature remains neutral with regard to jurisdictional claims in published maps and institutional affiliations. 


\section{Affiliations}

\section{László Vanyorek ${ }^{1}(1)$ Ádám Prekob ${ }^{1} \cdot$ Máté Baráth $^{1} \cdot$ Zoltán Németh $^{1}$.} Béla Fiser ${ }^{1,2} \cdot$ Béla Viskolcz ${ }^{1}$

$\triangle$ László Vanyorek

kemvanyi@uni-miskolc.hu

1 Institute of Chemistry, University of Miskolc, Miskolc-Egyetemváros 3515, Hungary

2 Ferenc Rákóczi II. Transcarpathian Hungarian Institute, Beregszász, Transcarpathia 90200, Ukraine 